\title{
Lean Practices Adoption in the Portuguese Industry
}

\author{
Diogo Martins ${ }^{1}$ (D) Luís Fonseca ${ }^{1,2}$ (ID), Paulo Ávila ${ }^{1}$ (D), João Bastos ${ }^{1,3}$ \\ ${ }^{1}$ Department of Mechanical Engineering, School of Engineering of Porto (ISEP), Polytechnic Institute of Porto (Portugal) \\ ${ }^{2} I N E G I$ - Instituto de Ciência e Inovacão em Engenharia Mecânica e Engenharia Industrial, Campus da FEUP, Rua Dr. Roberto \\ Frias, 400, 4200 - 465 Porto (Portugal) \\ ${ }^{3}$ Institute for Systems and Computer Engineering, Technology and Science (INESC TEC), School of Engineering of Porto (ISEP), \\ Polytechnic Institute of Porto (Portugal) \\ diogonunomartins.91@gmail.com,.lmf@isep.ipp.pt,psa@isep.ipp.pt,jab@isep.ipp.pt
}

Received: August 2020

Accepted: January 2021

\begin{abstract}
:
Purpose: The study purpose was to analyse the excellence and operational efficiency of Portuguese industrial companies through the measurement of lean practices implementation. Additionally, it intended to propose a new model to assess the lean production system.
\end{abstract}

Design/methodology/approach: The research presents an in-depth lean literature review that served as a basis for the creation of a questionnaire. The survey was addressed to Portuguese industrial companies to obtain data about their lean implementation success. Collected data were analysed, resorting descriptive and exploratory statistics. A principal component analysis was applied to reduce the amount of data and define a new model that characterizes the lean practices adoption level. Some Chi-square tests were used to assess the independence of some variables.

Findings: The results indicate that a significant percentage of organizations use lean practices within their activity. Concerning the lean implementation maturity, a plus side revealed by the study concerns the adoption of the teamwork, internal information shared principles, increase of process capability to produce conforming products, and reduction in set up times. On the other hand, responsibilities decentralization, more employees acting as team leaders, implementation of employees' suggestions, and interconnection with suppliers, are some of the principles that need to be given greater attention by the Portuguese industrial organizations. The key contribution consists of a new model for lean determinants based on three dimensions: work method, productive process elements, and work efficiency.

Originality/value: The present research provides a new Lean determinants model that allows understanding the importance of the operational efficiency provided by a mature lean production system, being the key to the competitiveness in the global business market.

Keywords: lean management, lean tools, lean adoption, Portuguese industry, value

\section{To cite this article:}

Martins, D., Fonseca, L., Ávila, P., \& Bastos, J. (2021). Lean practices adoption in the Portuguese industry. Journal of Industrial Engineering and Management, 14(2), 345-359. https://doi.org/10.3926/jiem.3291 


\section{Introduction}

Lean Management (LM) is a philosophy based on the lean principles developed in Toyota by Ohno (1988), focusing on waste elimination and continuous improvement. LM has been adopted in a variety of countries in several economic sectors, with reported improved results and competitiveness (Moyano-Fuentes \& Sacristán-Díaz, 2012). Research on the impact of LM on financial performance financial has shown that for research models considering financial and operational indicators and contextual factors, ere is a positive and significant impact of LM on financial performance (Camacho-Minãnoa, Moyano-Fuentes \& Sacristán-Diáz, 2013).

However, in addition to the intra-organizational aspects, the successful LM requires that Lean principles and practices be applied throughout the whole supply chain (Womack \& Jones, 1996; Hines, Holweg \& Rich, 2004). In this respect, companies that adopt LM need to ensure proper Top Management leadership, employee commitment, and training and an integrated and systemic approach (Comm \& Mathaisel, 2005). In addition to the implementation of Lean tools and techniques, cultural change and Lean organizational thinking are required for enduring results (Bhasin, 2008; Hines, Found, Griffiths \& Harrison, 2008). Moreover, they should seek integration with their key suppliers and customers (Pérez, Castro, Simons \& Giménez, 2010). However, the adoption of LM and lean tools and techniques by Portuguese companies has only been moderate. This study aims to analyze the deepness of the levels of both lean conceptions and implementation in the Portuguese industrial context. Therefore, it contributes to the Lean dissemination and adoption by Portuguese companies, aiming for their enduring business success by investigating the perception of these companies toward the Lean determinants, and the level of application of Lean tools and techniques. The paper will proceed as follows. After a literature review of Lean, the research methodology will be presented. The results and discussions will address the application with Lean within the respondent organization, and an exploratory statistical analysis will be performed to propose a new model for lean determinants based on three dimensions: work method, productive process elements, and work efficiency. The paper ends with the conclusion section, including the main research findings and the suggestions for future studies.

\section{Lean Literature Review}

Lean production or lean thinking (Womack, Jones \& Ross, 1990; Womack \& Jones, 1996, 2013) is an initiative focused on eliminating all waste (Muda) in processes that employs minimum resources for maximum output, or to do more with less. Lean emphasizes continual improvement and is supported by the following five principles (Womack \& Jones, 1996: page 10):

- Specify the value by specific products, e.g., the capacity provided to the ultimate end customer, at the right time, and an appropriate price.

- Identify the value stream for each product, and the flow can refer to the flow of people, materials, information, or capital.

- Make the value flow without interruptions. The objective is to have a continuous flow throughout the value chain, that is, without stoppages that imply the stopping or reduction of the activity.

- Let the customer pull value from the producer. Pull means that the production starts only to satisfy customer requests.

- Pursue perfection, which requires a constant effort to meet customer needs and eliminate "muda" (the Japanese word for waste).

Lean asks for minimal inventories and waiting time, internal customer pull (instead of push system) scheduling and cutting batch sizes, line balancing, and reducing actual process times. The Lean production systems are characterized by just-in-time supplier delivery, quick changeover times, a high quality, and ongoing improvement. Regarding the last one, Putnik and Ávila (2015) compile a set of useful mechanisms that may contribute to the continuous improvement purpose. 
Sousa, Aspinwall, Sampaio and Guimarães (2005), in a research of small and medium-sized enterprises, posit that employees' competence to select methods or tools for continuous improvement within organizations is generally low. In a study of 231 Portuguese companies certified by ISO 9001, only 31 companies (13.4\%) had implemented lean tools (Margaça, 2013). In another investigation encompassing 202 Portuguese companies (ISO 9001 certified), Fonseca, Lima and Silva (2015) concluded that 78\% used some basic quality tools, specially check sheets, flow charts, histograms and control charts, and only 39\% used more advanced quality tools (e.g., improvement teams and brainstorming). Fonseca and Domingues (2018) researched the adoption of continuous improvement methodologies by ISO 9001 Portuguese companies, with results showing a mildly use of Lean by those companies, with higher lean adoption in the industry than in the services.

Karlsson and Åhlström (1996) proposed a model for assessing the required changes towards lean production. Based on the principles of lean production, they identified determinants (and operationalized then in a measurable format) that can reflect the desired effort to become lean. The proposed determinants for lean, based on the lean principles are presented in Table 1 below.

\begin{tabular}{|c|c|}
\hline Determinant & Measurement \\
\hline Waste elimination (reduction in ...) & $\begin{array}{l}\text { a) Work in progress } \\
\text { b) Setup times } \\
\text { c) Distance covered by the material during production process }\end{array}$ \\
\hline Continuous improvement (Increase of ...) & $\begin{array}{l}\text { a) Number of suggestions by employee } \\
\text { b) } \% \text { of implemented suggestions }\end{array}$ \\
\hline Quality control implementation & $\begin{array}{l}\text { a) Increase of defects control automation } \\
\text { b) Increase of process controls } \\
\text { c) Increase of process capability to produce conforming products } \\
\text { d) Decrease of number people involved in quality control }\end{array}$ \\
\hline Just in time (Reduction in ...) & $\begin{array}{l}\text { a) Production time between set ups } \\
\text { b) An order lead time }\end{array}$ \\
\hline Pull production system (Increase of ...) & $\begin{array}{l}\text { a) Number of stages of according to demand production process } \\
\text { b) Planned orders in pull system }\end{array}$ \\
\hline Teamwork (Increase of ...) & $\begin{array}{l}\text { a) } \% \text { Employees working in teams } \\
\text { b) Number of tasks performed in teams } \\
\text { c) Tasks turnover in the team } \\
\text { d) Employee training }\end{array}$ \\
\hline Decentralization of responsibilities & $\begin{array}{l}\text { a) Increase of } \% \text { Team Leader able employees } \\
\text { b) Increase of } \% \text { of Employees that performed as Team Leader } \\
\text { c) Reduction of the organization hierarchical levels }\end{array}$ \\
\hline Interconnection with suppliers (Increase of ...) & $\begin{array}{l}\text { a) Audits by suppliers } \\
\text { b) Audits to the suppliers } \\
\text { c) Average time duration of contracts with suppliers }\end{array}$ \\
\hline Information system (Increase of ...) & $\begin{array}{l}\text { a) Frequency information is provided to Employees } \\
\text { b) Number of information availability areas } \\
\text { c) Number of tea performance metrics }\end{array}$ \\
\hline
\end{tabular}

Table 1. Lean determinants (Karlsson \& Åhlström, 1996)

Lean also asks for the application of several tools and methodologies. However previous research has highlighted that Portuguese companies have limited applicability of basic and advanced Quality Tools (Fonseca et al., 2015). The three basic Quality tools with higher utilization were Check sheets, Flow charts and Histograms (for Services) or Control Charts (for industry). Fonseca and Domingues (2018) in another research encompassing Portuguese ISO 9001 certified organizations, found that amongst the quality and engineering tools applied by the respondent organizations, checklists, PDCA cycle and process diagrams are the most frequently 
adopted. Table 2 presented below summarizes the Lean tools and methodologies that will be considered for this research.

Researchers have also been studying what are the critical factors for Lean Management (LM) success. Comm and Mathaisel (2005) posit the need for a proactive attitude to deal with the change to LM, with leadership and commitment of top management, supported by people training and a suitable performance monitoring system. For Bhasin (2008) and Hines et al. (2008) in addition to the implementation of Lean tools and techniques, cultural change and Lean organizational thinking are required for enduring results. Lewis (2000) and Shah and Ward (2007) posit that LM implementation should involve the overall organization, including both suppliers and customers. Bateman (2005) states that everyone should contribute and be committed toward LM with a focus on continuous improvement, and integration and deployment of the LM strategy at all the organization levels. Netland (2016) postulates that elements such as active leadership, personal participation, and a high level of lean knowledge by the employees and of the managers are some of the key factors, being the commitment for the continuous development of lean production system encouraged by the top management to the lower organizational positions. Mostafa, Dumrak and Soltan (2013) state that the development of lean practices implementation has an inherent correlation to the human element, e.g. a poor mindset and misunderstanding of lean concept strongly restricts the lean implementation development process and reduces the expected benefits for the organisation. The creation of Lean learning academies, as innovative framework for lean manufacturing training (Vaz de Carvalho et al., 2013), may contribute to enlarge the mindset of the employees and consecutively the lean practices implementation.

\begin{tabular}{c|cl} 
Tools and methodologies & Description
\end{tabular}

\begin{tabular}{|c|c|}
\hline $\begin{array}{l}\text { FMEA - Failure Mode and } \\
\text { Effects Analysis } \\
\text { (Stamatis, 1995) }\end{array}$ & $\begin{array}{l}\text { FMEA is a step-by-step method for identifying and evaluate the potential failure of a } \\
\text { product or process and its effects, identify actions that could eliminate or reduce the } \\
\text { occurrence of the potential failure and document the process. }\end{array}$ \\
\hline $\begin{array}{l}\text { Five S (Peterson \& Smith, } \\
\text { 1998) }\end{array}$ & $\begin{array}{l}\text { The } 5 \mathrm{~S} \text { approach organizes the workplace, keeps it neat and clean, establishes standardized } \\
\text { conditions and maintains discipline to sustain the effort. } 5 \mathrm{~S} \text { creates a workplace suited for } \\
\text { visual control and lean production and promotes visual management and standard ways of } \\
\text { working. } \\
\text { The five Japanese terms for } 5 \mathrm{~S} \text { are: Seiri means to separate needed tools, parts and } \\
\text { instructions from unneeded materials and to remove the unneeded ones; Seiton means to } \\
\text { simplify, set in order, and configure, ensuring parts are and tools can be easily identified and } \\
\text { used; Seiso means to conduct a cleaning campaign; Seiketsu means to standardize, stabilize, } \\
\text { and ensure conformity daily to maintain a workplace in perfect condition; and Shitsuke } \\
\text { means to form the habit of always following the first four S's. }\end{array}$ \\
\hline Jidoka (Monden, 1995) & $\begin{array}{l}\text { Jidoka is about quality at source or built-in quality. Jidoka empowers the worker as a thinker } \\
\text { and allows all workers the right to stop the line on which they are working. }\end{array}$ \\
\hline $\begin{array}{l}\text { TPM - Total Productive } \\
\text { Maintenance (Black, 2008) }\end{array}$ & $\begin{array}{l}\text { A series of methods, originally pioneered by Nippondenso (a member of the Toyota } \\
\text { group), to ensure every machine in a production process is always able to perform its } \\
\text { required tasks so production is never interrupted. }\end{array}$ \\
\hline $\begin{array}{l}\text { VSM - Value Stream Mapping } \\
\text { (Jones, 1995) }\end{array}$ & $\begin{array}{l}\text { VSM is a method to first, follow a product's production path from beginning to end and } \\
\text { draw a visual representation of every process in the material and information flows. } \\
\text { Second, the desired future state map of how value should flow is drawn, to reduce waste } \\
\text { and achieve lean production. }\end{array}$ \\
\hline $\begin{array}{l}\text { JIT - Just In Time (Lubben, } \\
\text { 1989) }\end{array}$ & $\begin{array}{l}\text { Just in Time is a production management system where everything must be produced, } \\
\text { transported, or purchased at the right time with the aim to reduce inventories and costs. }\end{array}$ \\
\hline $\begin{array}{l}\text { SMED - Single Minute } \\
\text { Exchange of Dies (Ohno, } \\
\text { 1988) }\end{array}$ & $\begin{array}{l}\text { SMED is a series of techniques pioneered by Shigeo Shingo for changeovers of } \\
\text { production machinery in less than } 10 \text { minutes. The long-term objective is always zero setup, } \\
\text { in which changeovers are instantaneous and do not interfere in any way with continuous } \\
\text { flow. }\end{array}$ \\
\hline Kanban (Ohno, 1988) & $\begin{array}{l}\text { KANBAN is a "pull" method for providing material/product to a succeeding operation by } \\
\text { signaling the preceding operation when more material/product is needed. }\end{array}$ \\
\hline
\end{tabular}




\begin{tabular}{|l|l|}
\hline \multicolumn{1}{|c|}{ Tools and methodologies } & \multicolumn{1}{c|}{ Description } \\
\hline $\begin{array}{l}\text { Visual management (Ohno, } \\
1988)\end{array}$ & $\begin{array}{l}\text { With visual management operators can quickly and accurately gauge production status } \\
\text { briefly, proving a sense of ownership in the working area. }\end{array}$ \\
\hline Standard work (Ohno, 1988) & $\begin{array}{l}\text { With standard work, there is a precise description of each work activity and all jobs are } \\
\text { organized around the human motion to create an efficient sequence without waste. The } \\
\text { three elements that make up standard work are takt time, working sequence and standard } \\
\text { in-process stock. }\end{array}$ \\
\hline Heinjuka (Ohno, 1988) & $\begin{array}{l}\text { The term Heijunka comes from Japanese and means leveling. It is a method for reducing } \\
\text { the unevenness in a production process and minimizing the chance of overburden. }\end{array}$ \\
\hline
\end{tabular}

Table 2. Lean tools and methodologies

This study addresses the perception of Portuguese companies toward the Lean determinants, and the level of application of Lean tools and techniques. Ultimately, it aims to contribute to intensify the adoption of continuous improvement methodologies (such as Lean) and related tools, to improve overall business performance by the Portuguese companies.

\section{Methodology}

This research aims to investigate the implementation of lean practices in the Portuguese industry. Data collection was made through an online survey addressed to the Portuguese industrial companies, intending to obtain assessments about their own lean implementation success. Google Forms software was used, allowing this platform to create a link, which followed in the email sent to all those invited to participate in the study. The survey started from the previous appreciation of a questionnaire subordinated to the lean (Moreira, 2011); however, it proceeded to the structuring and creation of a new questionnaire based on a new bibliographic study framed in the present dissertation (e.g., Karlsson \& Åhlström, 1996; Sánchez \& Pérez, 2001). The research methodology is presented in Figure 1.

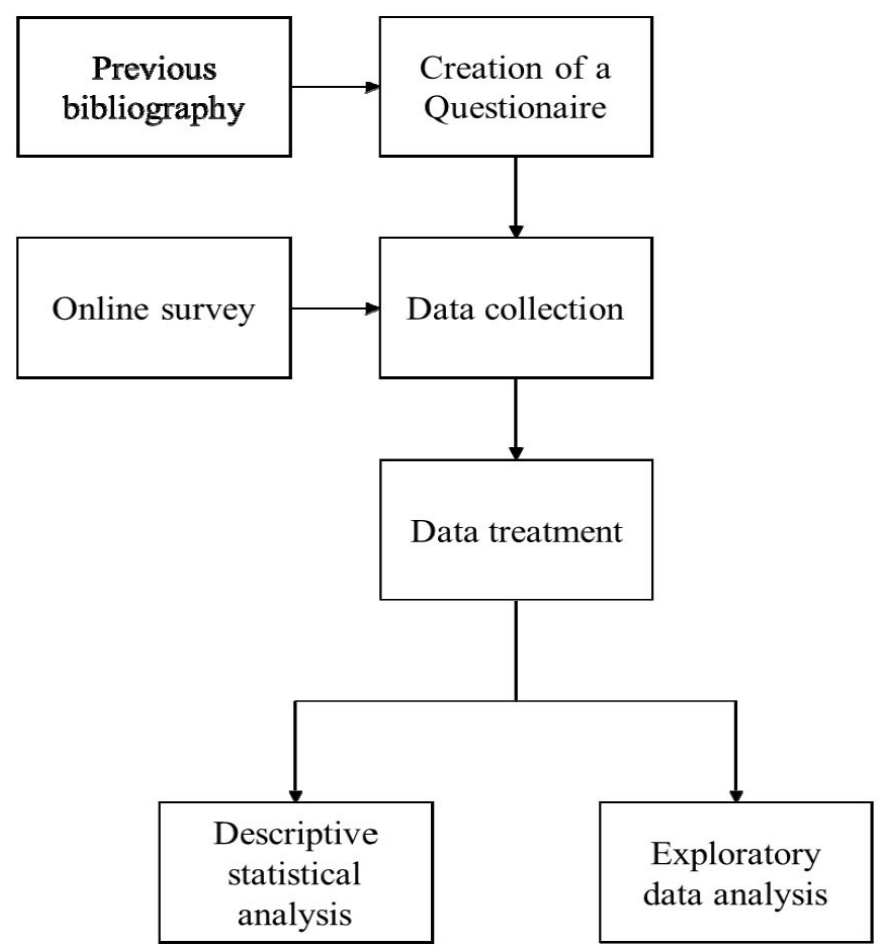

Figure 1. Research Methodology

The questionnaire is made up of four sections: Characterization of the organization, Lean in the organization, Lean manufacturing, and Lean Product Development. In all, there were 19 questions, some of them divided into 
paragraphs, and all of them are mandatory answers. It ends with a twentieth optional question in which an email address is requested, to convey the results obtained in the dissertation to all interested participants.

The questionnaire was available to be answered during September 2018. The universe understudy was 68,830 organizations, belonging to the territory of Mainland Portugal, Madeira, and the Azores. During this timeframe, approximately 600 organizations were contacted, with 31 valid responses obtained. The maximum margin of error associated with the sample is 17.6\%, with a 95\% confidence level. Statistical Package for Social Sciences 25 (SPSS) was used for the statistical treatment of data.

Based on the obtained data, two types of analysis were performed: descriptive statistics, where the obtained results were described, and exploratory statistics, in which the internal consistency of the answers was validated and the correlation between variables was performed. The survey results suggest that the sample is representative of the population, since the distribution by company sector, follows that of the population.

To search for potential non-respondent, bias the results from late, and early respondents were monitored, and no significant differences were found. Construct reliability was tested and validated with Cronbach Alpha. The Cronbach's alpha analysis test (Cronbach, 1951) estimates that the internal consistency of responses, based on item variances and test totals per subject (per participant) was higher than 0.9 , confirming the survey's validity.

\section{Results and Discussions}

\subsection{Sample Characterization}

There is an overwhelming majority of companies with national capital and headquarters in Portugal, amounting to a value close to $60 \%$. Besides, there are almost a quarter of organizations with headquarters abroad and with majority capital, which have a productive center (s) in Portugal. Manufacture of motor vehicles, trailers, semi-trailers and motor vehicle components, Manufacture of electrical and optical equipment, Manufacture of chemicals and human-made fibers, Manufacture of chemical products, and human-made fibers, represent more than $50 \%$ of the respondent organizations. More than $80 \%$ of the sample companies had more than 50 employees, having almost $50 \%$ with more than 250 workers.

The organizations that responded using lean tools in their activity (24 participants) were asked for the list of tools they use within their activity, allowing the selection of as many as the participant wanted to list. Table 3 shows the absolute and relative frequencies.

\begin{tabular}{|l|c|}
\hline \multicolumn{1}{|c|}{ Lean tools } & Relative frequency \\
\hline 5 S & $95.8 \%$ \\
\hline Visual management & $79.2 \%$ \\
\hline SMED & $70.8 \%$ \\
\hline Standard work & $66.7 \%$ \\
\hline FMEA & $66.7 \%$ \\
\hline Value Stream Mapping & $45.8 \%$ \\
\hline Heijunka & $29.2 \%$ \\
\hline Jidoka & $29.2 \%$ \\
\hline TPM & $12.5 \%$ \\
\hline Kanban & $8.3 \%$ \\
\hline
\end{tabular}

Table 3. Lean tools application

Almost all organizations use the $5 \mathrm{~S}$ methodology during their activity. At least two thirds $(2 / 3)$ of companies also use tools such as Visual Management, SMED, Standardized Work, and FMEA, while the use of Value Stream Mapping is limited to coverage close to half of the participants. Heijunka and Jidoka do not have very wide 
acceptance, with one-third of organizations not reaching their use. The adoption of TPM and Kanban was not included in the original survey but were added from some participants.

Concerning participants' perception of the maturity of their lean system (see Figure 2), 45.8\% consider having a lean system with medium maturity. Besides, the fraction of organizations that assess their state of maturity of lean implementation as "High" or "Very high" amounts to one third (1/3) of those eligible. Conversely, there are still more than a fifth $(1 / 5)$ of organizations that consider the state of maturity of lean implementation to be reduced, emphasizing that there is an opportunity further to increase the adoption of Lean by Portuguese companies.

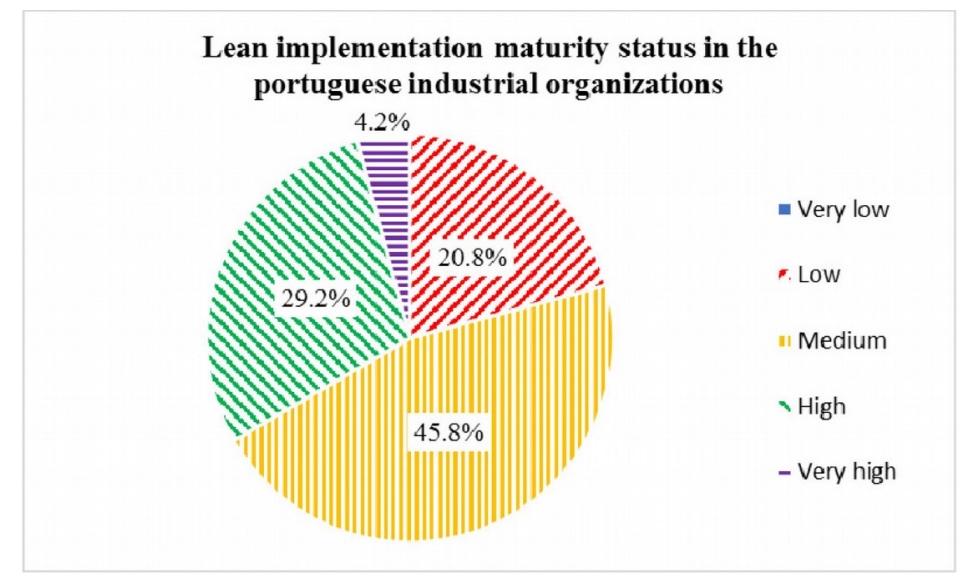

Figure 2. Lean implementation maturity status

\subsection{Lean Implementation Success Level}

This section aims to assess the degree of success that lean implementation causes in the organization's production and the results summarized in Table 4 below.

\begin{tabular}{|c|c|c|c|c|}
\hline $\begin{array}{c}\text { Lean } \\
\text { determinant }\end{array}$ & $\begin{array}{c}\text { Measures to assess } \\
\text { changes towards } \\
\text { (Karlsson \& Ảlström, 1996) }\end{array}$ & Mean & $\begin{array}{c}\text { Std } \\
\text { Deviation }\end{array}$ & Comments \\
\hline \multirow{3}{*}{$\begin{array}{l}\text { Waste } \\
\text { elimination } \\
\text { (reduction in } \\
\ldots \text { ) }\end{array}$} & a) Work in progress & 3.31 & 0.78 & \multirow{3}{*}{$\begin{array}{l}\text { The mode of the answers to characteristics a) } \\
\text { and c) is at the "Medium" scale level; c) is } \\
\text { bimodal between the "Medium" and "High" } \\
\text { levels; Prevalence of responses to the right side } \\
\text { of the scale, evidencing success in the principle } \\
\text { implementation; The setup times reduction is } \\
\text { the characteristic with the best degree of } \\
\text { success. }\end{array}$} \\
\hline & b) Setup times & 3.50 & 0.65 & \\
\hline & $\begin{array}{l}\text { c) Distance covered by the material } \\
\text { during production process }\end{array}$ & 3.13 & 0.88 & \\
\hline \multirow{2}{*}{$\begin{array}{l}\text { Continuous } \\
\text { improvement } \\
\text { (Increase of } \\
\ldots \text { ) }\end{array}$} & $\begin{array}{l}\text { a) Number of suggestions by } \\
\text { employee }\end{array}$ & 3.25 & 0.97 & \multirow{2}{*}{$\begin{array}{l}\text { For characteristic a) the mode is presented at } \\
\text { "High" scale level, while for b) is at "Medium" } \\
\text { level; The proportions of the answers obtained } \\
\text { in the "Medium" and "High" scale levels are } \\
\text { similar to the inversely proportional ones. }\end{array}$} \\
\hline & b) $\%$ of implemented suggestions & 3.04 & 0.84 & \\
\hline \multirow{4}{*}{$\begin{array}{l}\text { Quality control } \\
\text { implementation }\end{array}$} & $\begin{array}{l}\text { a) Increase of defects control } \\
\text { automation }\end{array}$ & 3.00 & 0.82 & \multirow{4}{*}{$\begin{array}{l}\text { The mode of a) b) and d) are presented at the } \\
\text { "Medium" scale level; More than } 2 / 3 \text { present a } \\
\text { success degree above "Medium" level, relative } \\
\text { to their process capability; Low success degree } \\
\text { in the reduction of people belonging to the } \\
\text { quality control. }\end{array}$} \\
\hline & b) Increase of process controls & 3.25 & 0.92 & \\
\hline & $\begin{array}{l}\text { c) Increase of process capability to } \\
\text { produce conforming products }\end{array}$ & 3.67 & 0.85 & \\
\hline & $\begin{array}{l}\text { d) Decrease of number people } \\
\text { involved in quality control }\end{array}$ & 2.54 & 0.76 & \\
\hline
\end{tabular}




\begin{tabular}{|c|c|c|c|c|}
\hline $\begin{array}{c}\text { Lean } \\
\text { determinant }\end{array}$ & $\begin{array}{c}\text { Measures to assess } \\
\text { changes towards } \\
\text { (Karlsson \& Åhlström, 1996) }\end{array}$ & Mean & $\begin{array}{c}\text { Std } \\
\text { Deviation }\end{array}$ & Comments \\
\hline \multirow{2}{*}{$\begin{array}{l}\text { Just in time } \\
\text { (Reduction in } \\
\ldots \text { ) }\end{array}$} & $\begin{array}{l}\text { a) Production time between set } \\
\text { ups }\end{array}$ & 3.25 & 0.97 & \multirow{2}{*}{$\begin{array}{l}\text { The mode of answers to case a) is at the } \\
\text { "Medium" scale level, while at characteristic b) } \\
\text { is at the "High "one. } \\
\text { The reduction of the production time between } \\
\text { setups can be explained by an increase in the } \\
\text { productive circuit flexibility. } \\
\text { Reducing the lot production time may allow a } \\
\text { lower level of WIP and an increase in the } \\
\text { customer service level. }\end{array}$} \\
\hline & b) An order lead time & 3.29 & 0.93 & \\
\hline \multirow{2}{*}{$\begin{array}{l}\text { Pull production } \\
\text { system } \\
\text { (Increase of } \\
\ldots \text { ) }\end{array}$} & $\begin{array}{l}\text { a) Number of stages of according } \\
\text { to demand production process }\end{array}$ & 2.88 & 0.73 & \multirow{2}{*}{$\begin{array}{l}\text { The mode of the results are at the "Medium" } \\
\text { scale level to both characteristics; More than } \\
80 \% \text { of respondents rated the increase in } \\
\text { planned orders in the pull system as } \\
\text { "Medium" or higher; } 1 / 3 \text { of the } \\
\text { organizations classified as "Low" the } \\
\text { achieved success in terms of the number of } \\
\text { stages of the production. }\end{array}$} \\
\hline & b) Planned orders in pull system & 3.12 & 0.78 & \\
\hline \multirow{4}{*}{$\begin{array}{l}\text { Teamwork } \\
\text { (Increase of } \\
\ldots \text { ) }\end{array}$} & a) $\%$ Employees working in teams & 3.58 & 0.91 & \multirow{4}{*}{$\begin{array}{l}\text { The mode of the answers in cases a) and c) } \\
\text { are at the "Medium" level of the scale, while } \\
\text { characteristics b) and d) are at the "High" } \\
\text { level; The characteristic of training provided } \\
\text { to employees presents the most positive } \\
\text { result, with more than half of the participants } \\
\text { assessing the success degree as "High" or } \\
\text { "Very high". }\end{array}$} \\
\hline & $\begin{array}{l}\text { b) Number of tasks performed in } \\
\text { teams }\end{array}$ & 3.38 & 0.81 & \\
\hline & c) Tasks turnover in the team & 3.46 & 0.96 & \\
\hline & d) Employee training & 3.67 & 0.90 & \\
\hline \multirow{3}{*}{$\begin{array}{l}\text { Decentralizatio } \\
\mathrm{n} \text { of } \\
\text { responsibilities }\end{array}$} & $\begin{array}{l}\text { a) Increase of } \% \text { Team Leader able } \\
\text { employees }\end{array}$ & 2.88 & 0.93 & \multirow{3}{*}{$\begin{array}{l}\text { The mode of the results of characteristics a) } \\
\text { and c) are in the "Medium" level of the scale, } \\
\text { however the characteristic b) is at the "Low" } \\
\text { level; The characteristic that presents more } \\
\text { modest results concerns the reduction of the } \\
\text { hierarchical levels within the organizations. }\end{array}$} \\
\hline & $\begin{array}{l}\text { b) Increase of } \% \text { of Employees } \\
\text { that performed as Team Leader }\end{array}$ & 2.96 & 0.89 & \\
\hline & $\begin{array}{l}\text { c) Reduction of the organization } \\
\text { hierarchical levels }\end{array}$ & 2.54 & 0.87 & \\
\hline \multirow{3}{*}{$\begin{array}{l}\text { Interconnection } \\
\text { with suppliers } \\
\text { (Increase of } \\
\ldots \text { ) }\end{array}$} & a) Audits by suppliers & 2.79 & 0.96 & \multirow{3}{*}{$\begin{array}{l}\text { The mode of the results of characteristics a) } \\
\text { and c) are at the "Medium" level of the scale, } \\
\text { however the characteristic b) is at the "Low" } \\
\text { level; None of the characteristics present } \\
\text { more than } 1 / 4 \text { of the ratings higher than the } \\
\text { "Medium" scale level. }\end{array}$} \\
\hline & b) Audits to the suppliers & 2.75 & 1.01 & \\
\hline & $\begin{array}{l}\text { c) Average time duration of } \\
\text { contracts with suppliers }\end{array}$ & 2.83 & 0.75 & \\
\hline \multirow{3}{*}{$\begin{array}{l}\text { Information } \\
\text { system } \\
\text { (Increase of } \\
\ldots \text { ) }\end{array}$} & $\begin{array}{l}\text { a) Frequency information is } \\
\text { provided to Employees }\end{array}$ & 3.79 & 0.91 & \multirow{3}{*}{$\begin{array}{l}\text { The mode of the results is "High" scale level } \\
\text { for characteristic a), Medium" scale level for } \\
\text { characteristic b), and Bimodal between } \\
\text { "Medium" and "High" scale level for } \\
\text { characteristic c). Most of the evaluations are } \\
\text { at the "Medium" level of the scale or to the } \\
\text { positive scale levels. }\end{array}$} \\
\hline & $\begin{array}{l}\text { b) Number of information } \\
\text { availability areas }\end{array}$ & 3.67 & 0.94 & \\
\hline & $\begin{array}{l}\text { c) Number of key performance } \\
\text { metrics }\end{array}$ & 3.63 & 0.95 & \\
\hline
\end{tabular}

Table 4. Descriptive statistics for Lean determinants and assessment measures

These results highlight the following findings:

- Support for the success in waste elimination with Lean. The setup times reduction is the characteristic with the best degree of success, which is consistent with the high level of application of 5S, visual management, and SMED, which all set up time reduction. 
- There is a considerable margin for progression in continuous improvement, e.g., implementing improvement suggestions from employees.

- There are positive results concerning the increase of process capability to produce conforming products, probably due to the increase of process control. However, there is an apparent difficulty in reducing employees involved in quality control. Part of the explanation may come from the median result presented by the characteristic that affects the automation of defect control.

- There is a decrease in the production time between setups, which can be explained by an increase in the productive circuit flexibility. The same applies to the lot production time reduction that may allow a lower level of WIP and an increase in the customer service level.

- The implementation of the pull production system shows an average degree of success. Despite this, the increase in orders planned under the pull regime stands out positively, also inferring a lesser willingness of organizations to increase the number of stages of the production process based on this regime.

- The $\%$ of employees qualified and acting as team leaders can still be improved. The reduction of the hierarchical levels within the organizations presents more modest results.

- The level of interconnection with suppliers is quite modest, requiring a more intensive collaboration supply chain.

- The results concerning the information system indicate that the organizations are concerned with having information transmission policies, as well as ways of analyzing and evaluating team performance.

\subsection{Exploratory Data Analysis}

\subsubsection{Principal Components Analysis}

After the Descriptive statistical analysis, an exploratory data analysis was performed applying principal component analysis with the objective analysing the main components and selecting the components that explain most of the total variation, reducing the size of the data. A factor analysis (extraction through the maximum likelihood method) of the results was carried out and the maximum likelihood method (ML) was used (Hair, Black, Babin, Anderson, \& Tatham, 2010). Bartlett's test of sphericity (testing the overall significance of all the correlations within the correlation matrix) was significant, suggesting the appropriateness of using the factor analytic model. The KaiserMeyer-Olkin (sampling adequacy) $(\mathrm{KMO}=0.671)$ pointed out the relationships among the variables suggested it was acceptable to proceed with the factor analysis.

The application of the factor reduction leads to the distribution of the results in three main components, according to the results presented in Table 5.

\section{Total Variance Explained}

\begin{tabular}{|c|c|c|c|c|c|c|c|c|c|}
\hline \multirow[b]{2}{*}{ Component } & \multirow[b]{2}{*}{ Total } & \multicolumn{2}{|c|}{ Initial Eigenvalues } & \multicolumn{3}{|c|}{ Extraction Sums of Squared Loadings } & \multicolumn{3}{|c|}{ Rotation Sums of Squared Loadings } \\
\hline & & $\%$ of Variance & Cumulative \% & Total & $\%$ of Variance & Cumulative $\%$ & Total & $\%$ of Variance & Cumulative $\%$ \\
\hline 1 & 4.061 & 45.123 & 45.123 & 4.061 & 45.123 & 45.123 & 2.803 & 31.149 & 31.149 \\
\hline 2 & 1.362 & 15.135 & 60.258 & 1.362 & 15.135 & 60.258 & 2.253 & 25.034 & 56.183 \\
\hline 3 & 1.096 & 12.176 & 72.433 & 1.096 & 12.176 & 72.433 & 1.463 & 16.251 & 72.433 \\
\hline 4 & .807 & 8.961 & 81.395 & & & & & & \\
\hline 5 & .562 & 6.246 & 87.641 & & & & & & \\
\hline 6 & .482 & 5.352 & 92.992 & & & & & & \\
\hline 7 & .287 & 3.189 & 96.181 & & & & & & \\
\hline 8 & .238 & 2.642 & 98.823 & & & & & & \\
\hline 9 & .106 & 1.177 & 100.000 & & & & & & \\
\hline
\end{tabular}

Table 5. Total Variance Explained (output from SPSS) 
The component matrix allows relating each component with each of the nine evaluated lean manufacturing determinants. In order to present a simplified and optimized structure, the rotation of the matrix was applied, reaching the greater possible degree of independence between the components' load (Table 6).

The obtained result allows associating the determinants in the following manner: component 1 (Determinants 7, 6 and 4), component 2 (Determinants 2, 9,8 and 3) and component 3 (Determinants 5 and 1).

The correlations showed by the rotated component matrix can also be presented in a graphical form, corresponding each red contour line to a component (Figure 3).

\section{Rotated Component Matrix ${ }^{a}$}

\begin{tabular}{ll|l|l} 
& \multicolumn{3}{c}{ Component } \\
& 1 & 2 & 3 \\
\hline Determinant7 & .894 & & .261 \\
\hline Determinant6 & .868 & & \\
\hline Determinant4 & .834 & .340 & \\
\hline Determinant2 & .151 & .869 & -.121 \\
\hline Determinant9 & & .719 & .110 \\
\hline Determinant8 & & .602 & .512 \\
\hline Determinant3 & .555 & .561 & .227 \\
\hline Determinant5 & .126 & & .924 \\
\hline Determinant1 & .436 & .426 & .442 \\
\hline Extraction & & & \\
\hline
\end{tabular}

Extraction Method: Principal Component Analysis.

Rotation Method: Varimax with Kaiser

Normalization.

a. Rotation converged in 4 iterations.

Table 6. Rotated Component Matrix (output from SPSS)

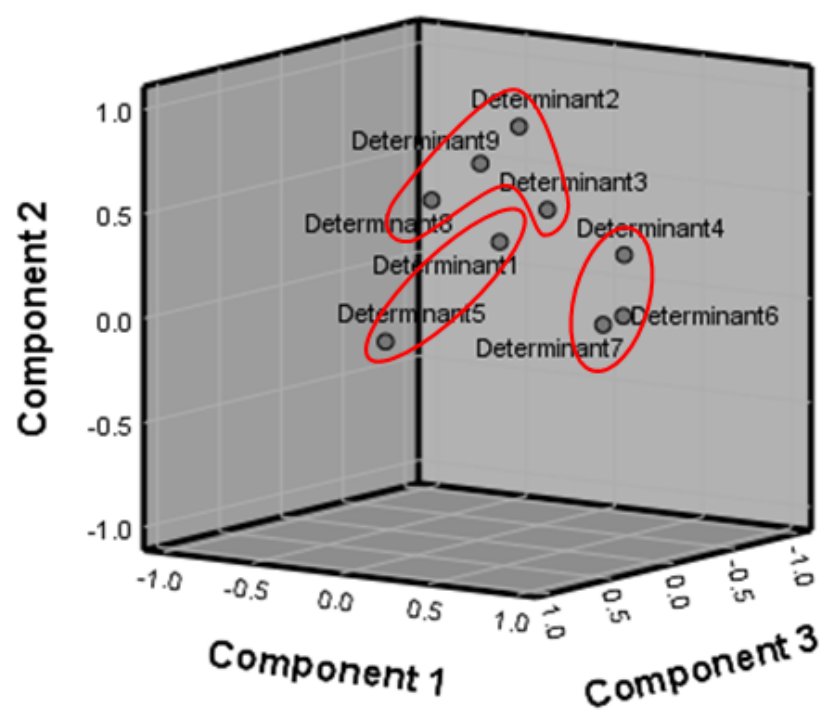

Figure 3. Component plot in rotated space

The original nine Lean determinants have been reduced to three main components presented in Table 7 . The new designated Lean determinants allow characterizing, in a more simple way and of a high degree of reliability, the Portuguese organizations by its lean practices system. Component 1 refers to the organizations' work method, 
component 2 indicates the productive processes characteristics, and component 3 points out the organizations' capability of working in an environment focused on efficiency.

\begin{tabular}{|l|l|}
\hline \multicolumn{1}{|c|}{ Original Lean determinant } & \multicolumn{1}{c|}{ New Lean determinant } \\
\hline $\begin{array}{l}\text { Responsibilities decentralization } \\
\text { Teamwork }\end{array}$ & Work method \\
Just in time & \\
\hline $\begin{array}{l}\text { Continuous improvement } \\
\text { Information system } \\
\text { Interconnection with suppliers } \\
\text { Quality control }\end{array}$ & \\
\hline Pull production system & Productive process elements \\
Waste elimination & Work efficiency \\
\hline
\end{tabular}

Table 7. New Lean determinants

\subsubsection{Tests of Association}

As a complement of the new lean determinants model, some of the variables extracted from the questionnaire results were used to enrich and deepen the study with the assessment of the dependence of that variables, trying to create new interconnections regarding lean production systems of the Portuguese industrial organizations.

In order to assess the dependence between the lines and of the columns of a table composed of two nominal variables or one nominal and another ordinal, the chi-square independence test is considered an adequate statistic technic (Martins, 2011).

The chi-squared test for independence is based on a table of observed counts from a bivariate qualitative data set, and it is computed from a table that gives the counts you would expect if the two variables were independent (Siegel, 2016).

The statistical study intends to verify the dependence between the following three variables (Table 8): the size of an organization in terms of its human resources, the maturation level of lean practices implementation, and the usage of lean product development methodologies. The used variables allow reaching three of the questionnaire sections, namely the characterization of an organization, the lean in the organization, and lean product development, becoming stronger the lean practices implementation study.

\begin{tabular}{|c|l|l|}
\hline Hypotheses number & \multicolumn{1}{|c|}{ Formulation } & \multicolumn{1}{c|}{ Description } \\
\hline Hypothesis 1 & $\begin{array}{l}\mathrm{H}_{0}: \text { There is no association ... } \\
\mathrm{H}_{1}: \text { There is association ... }\end{array}$ & $\begin{array}{l}\text {. } \\
\text { organization, and the maturation level of lean practices } \\
\text { implementation. }\end{array}$ \\
\hline Hypothesis 2 & $\begin{array}{l}\mathrm{H}_{0}: \text { There is no association ... } \\
\mathrm{H}_{1}: \text { There is association ... }\end{array}$ & $\begin{array}{l}\text {... between the number of employees of the } \\
\text { organizations, and the usage of lean product } \\
\text { development methodologies. }\end{array}$ \\
\hline Hypothesis 3 & $\begin{array}{l}\mathrm{H}_{0}: \text { There is no association ... } \\
\mathrm{H}_{1}: \text { There is association ... }\end{array}$ & $\begin{array}{l}\text {.. between the usage of lean product development } \\
\text { methodologies, and maturation level of lean practices } \\
\text { implementation. }\end{array}$ \\
\hline
\end{tabular}

Table 8. Hypothesis summary

A chi-square test was performed to assess all the proposed hypothesis using SPSS software, and the summarized results are presented in Table 9.

Regarding the results, in all the cases the 2-sided asymptotic significance presents a value above 0.05 (the significance level), indicating that there is no association between the variables, and of being the three hypothesis accepted. These results allow claiming that there is no evidence that the number of human resources in an organization does influence the maturation of its production system. In the same perspective, the number of 
employees does not present a relevant association with the usage of lean product development methodologies. What concerns the third hypothesis, the usage of lean techniques in product development work does not have a significant association with its production system maturation, indicating the independence of the variables.

\begin{tabular}{|c|c|c|}
\hline Hypothesis Number & Value & Asymptotic Significance (2-sided) \\
\hline Hypothesis 1 & 3.476 & 0.324 \\
\hline Hypothesis 2 & 1.865 & 0.601 \\
\hline Hypothesis 3 & 3.370 & 0.338 \\
\hline
\end{tabular}

Table 9. Chi-square test results

\section{Conclusions}

It is possible to say that there is a generalization of basic tools usages, such as $5 \mathrm{~S}$ and visual management, but also of more technical tools such as SMED, standardized work, and FMEA. Regarding success degree of Lean Manufacturing principles application, it is verified:

- A great percentage of the respondent organizations use lean practices within their activity.

- A positive result in adopting the principles of teamwork and the internal information system.

- An increase of process capability to produce conforming products.

- A reduction in set up times.

- On the other hand, responsibilities decentralization, more employees acting as team leaders, implementation of employees' suggestions, and interconnection with suppliers, are some of the principles that need to be given greater attention by the Portuguese industrial organizations.

- The lean implementation in the Portuguese industry organizations presents a medium degree of success, and there is still a long way to improve the organizational systems.

As stated by Lewis (2000), Shah and Ward (2007) and Pérez et al. (2010), Lean Management implementation should involve in addition to the overall organization, also suppliers and customers, which has proved to be a weak point in this investigation. The utilization of Lean tools is more intense with this study than another previous research (e.g., Sousa et al., 2005; Fonseca et al., 2015; Fonseca \& Domingues, 2018). However, it can be highlighted as posit by Bhasin (2008) and Hines et al. (2008), that in addition to the implementation of Lean tools and techniques, cultural change and Lean organizational thinking are required for enduring results.

This research is a relevant contribution to the research addressing the Portuguese industry's Lean practices implementation study. It has both Managerial and theoretical implications by confirming the Portuguese organizations' perception of the benefits of Lean implementation and the applicable tools more positive way than previous research. Managers will, therefore, be able to make better and more effective decisions about the implementation of a Lean, while in terms of theoretical value, this investigation contributes to the Lean methodology and tools literature by suggesting a new model for lean determinants based on three dimensions: work method, productive process elements, and work efficiency.

The complementary study to assess the dependence of some variables into an organization resorted variables not directly considered for the new lean determinants model, trying to found associations that allow us to go deeper in the lean implementation study by Portuguese industrial organizations. They focused on the size of the organizations, its lean practices' perception, and lean product development methodologies. The obtained results allow us to conclude that all of the variables have no dependence between them.

As postulate by Mostafa et al. (2013) and Netland (2016), the human factor is an inherent integral component of the lean manufacturing system. Regardless of the number of employees of an organization, the lean maturation stage or the usage of lean product development methodologies, the dependence of the variables needs an active leadership, encouraging all the employees for continuous improvement, beginning on the top management, and involving all the organization and its stakeholders. Existing research (Fonseca, Esteves, Ghinea \& Cantaragiu, 2019), 
posits that "Portuguese organizations show a level of organizational hybridism with several organizational models applied simultaneously and emphasis on dialogue, flexibility, and response capability". Nevertheless, the organizational culture and the human characteristics of the leadership in the industrial Portuguese organizations should be taken into consideration in additional studies regarding the influence of each human factor for the continuous improvement progress towards lean practices success. Additionally, the measure of continuous improvement made by the quantity of ideas and of its implemented percentage does not specifically address the impact (e.g., cost benefit) of the specific implemented ideas, suggesting the adoption of additional measures for future studies.

The small sample size restricted to Portuguese companies, suggest caution to generalize these results. Additional research with a higher and more diversified sample of companies and other countries will be necessary for generalization. Another suggestion for future studies will be to address the relationships of Lean with Supply Chain Management and Sustainability.

\section{Acknowledgments}

The authors would like to thank BS18 International Conference on Business Sustainability Conference Editors, Professors Goran Putnik, and Paula Ávila, for their continuous and highly valuable support in this research field. The authors also thank and all the BS18 Conference participants for the valuable incentives to proceed this investigation.

\section{Declaration of Conflicting Interests}

The authors declared no potential conflicts of interest with respect to the research, authorship, and/or publication of this article.

\section{Funding}

The authors received no financial support for the research, authorship, and/or publication of this article.

\section{References}

Bateman, N. (2005). Sustainability: the elusive element of process improvement. International Journal of Operations \& Production Management, 25(3), 261-276. https://doi.org/10.1108/01443570510581862

Bhasin, S. (2008). Lean and performance measurement. Journal of Manufacturing Technology Management, 19(5), 670-684. https://doi.org/10.1108/17410380810877311

Black, J.R. (2008). Lean Production: Implementing a World-Class System. Industrial Press Inc.

Camacho-Minãnoa, M.del-M., Moyano-Fuentes, J., \& Sacristán-Diáz, M. (2013). What can we learn from the evolution of research on lean management assessment? International Journal of Production Research, 51(4), 1098-1116. https://doi.org/10.1080/00207543.2012.677550

Comm, C.L., \& Mathaisel, D.F.X. (2005). A case study in applying lean sustainability concepts to universities. International Journal of Sustainability in Higher Education, 6(2), 134-146. https://doi.org/10.1108/14676370510589855

Cronbach, L.J. (1951). Coefficient alpha and the internal structure of tests. Psychometrika, 16(3), 297-334. https://doi.org/10.1007/BF02310555

Fonseca, L.M., Lima, V., \& Silva, M. (2015). Utilization of quality tools: does sector and size matter? International Journal for Quality Research, 9(4), 605-620. http://ijgr.net/journal/v9-n4/4.pdf

Fonseca, L.M., \& Domingues, J.P. (2018). The Best of Both Worlds? Use of Kaizen and Other Continuous Improvement Methodologies within Portuguese ISO 9001 Certified Organizations. TQM Journal. https://doi.org/10.1108/TQM-12-2017-0173

Fonseca, L.M., Esteves, W., Ghinea, V.M., \& Cantaragiu, R.G. (2019). Mapping of organizational models in Portuguese companies. International Journal for Quality Research, 13(4), 811-822. https://doi.10.24874/IJQR13.04-04 
Jones, D.T. (1995). Corporate renewal through lean design. World Class Design to Manufacture, 2(2), 6-9. https://doi.org/10.1108/09642369310081882

Hair, J.F., Black, W.C., Babin, B.J., Anderson, R.E., \& Tatham, R.L. (2010). Multivariate Data Analysis: Global Edition (7th Edition). Upper Saddle River, NJ: Pearson.

Hines, P., Holweg, M., \& Rich, N. (2004). Learning to evolve: a review of contemporary lean thinking. International Journal of Operations \& Production Management, 24(10), 994-1011. https://doi.org/10.1108/01443570410558049

Hines, P., Found, P., Griffiths, G., \& Harrison, R. (2008). Staying Lean: Thriving, Not Just Surviving. Lean Enterprise Research Centre, Cardiff University, Cardiff.

Karlsson, C., \& Åhlström, P. (1996). Assessing changes towards lean production. International Journal of Operations \& Production Management, 16(2), 24-41. https://doi.org/10.1108/01443579610109820

Lewis, M.A. (2000). Lean production and sustainable competitive advantage. International Journal of Operations do Production Management, 20(8), 959-978. https://doi.org/10.1108/01443570010332971

Lubben, R.T. (1989). Just-In-Time: uma estratégia avançada de produção (Just-in-Time: an advanced production strategy). São Paulo, McGraw-Hill.

Margaça, J.M. (2013). Lean-ISO 9001: Estudo sobre a Valorização do Sistema de Gestão da Qualidade através da Utilização de ferramentas Lean. MSc Thesis, ISCTE, Lisbon.

Martins, C. (2011). Manual de Análise de Dados Quantitativos Com Recurso Ao IBM SPSS: Saber Decidir, Fazer, Interpretar e Redigir. Edited by Psiquilíbrios. Braga.

Monden, Y. (1995). Toyota Production System, Third Edition, 1995 - 041283930X.

Moreira, F. (2011). Estudo da Implementação da Filosofia Lean na Indústria Portuguesa. MSc Thesis, Instituto Superior de Engenharia do Porto, Porto.

Moyano-Fuentes, J., \& Sacristán-Díaz, M. (2012). Learning on lean: a review of thinking and research. International Journal of Operations \& Production Management, 32(5), 551-82, https://doi.org/10.1108/01443571211226498

Mostafa, S., Dumrak, J., \& Soltan, H. (2013). A Framework for Lean Manufacturing Implementation. Production and Manufacturing Research. https://doi.org/10.1080/21693277.2013.862159

Netland, T. (2016). Critical Success Factors for Implementing Lean Production: The Effect of Contingencies. International Journal of Production Research. https://doi.org/10.1080/00207543.2015.1096976

Ohno, T. (1988). Toyota Production System: Beyond Large-Scale Production (English translation ed.). Portland, Oregon.

Pérez, C., Castro, R., Simons, D., \& Giménez, G. (2010). Development of lean supply chains: a case study of the Catalan pork sector. Supply Chain Management International Journal, 15(1), 55-68.

https://doi.org/10.1108/13598541011018120

Peterson, J., \& Smith, R. (1998). O Guia de Bolso do 5S. Productivity Pres.

Putnik, G., \& Ávila, P. (2015) Mechanisms to Promote Continuous Improvement in Quality Management Systems. International Journal for Quality Research, 9(1), 1-8.

Sánchez, A.M., \& Pérez, M.P. (2001). Lean indicators and manufacturing strategies. International Journal of Operations \& Production Management, 21(11), 1433-1452. https://doi.org/10.1108/01443570110407436

Shah, R., \& Ward, P.T. (2007). Defining and developing measures of lean production. Journal of Operations Management, 25(4), 785-805. https://doi.org/10.1016/j.jom.2007.01.019

Siegel, A. (2016). Chi-Squared Analysis: Testing for Patterns in Qualitative Data (Chapter 17). In Andrew, F.B.T. (ed.), Practical Business Statistics (7th ed.) (509-524). Academic Press. https://doi.org/10.1016/B978-0-12-804250-2.00017-1 
Sousa, S.D., Aspinwall, E., Sampaio, P.A., \& Guimarães, A. (2005). Performance measures and quality tools in Portuguese small and medium enterprises: survey results. Total Quality Management, 16(2), 277-307. https:// doi.org/10.1080/14783360500054434

Stamatis, D.H. (1995). Failure Mode and Effect Analysis: FMEA from Theory to Execution. ASQ Quality Press.

Vaz de Carvalho, C., Pereira Lopes, M., Ramos, G., Ávila, P., Bastos, J., Fonseca, L., et al. (2013). Lean Learning Academy: an innovative framework for lean manufacturing training. Proceedings of the 1 st International Conference of the Portuguese Society for Engineering Education - CISPEE 2013, IEEE.

Womack, J., Jones, P., \& Ross, D. (1990). The Machine that Changed the World. New York, NY: Rawson, Associates

Womack, J.P., \& Jones, D.T. (1996). Lean Thinking: Banish Waste and Create Wealth in your Corporation. London: Simon \& Schuster. https://doi.org/10.1057/palgrave.jors.2600967

Womack, J.P., \& Jones, D.T. (2013). Lean Thinking: Banish Waste and Create Wealth in Your Corporation. London: Simon \& Schuster.

Journal of Industrial Engineering and Management, 2021 (www.jiem.org)

\section{(ㄷ) (1) $\Theta$}

Article's contents are provided on an Attribution-Non Commercial 4.0 Creative commons International License. Readers are allowed to copy, distribute and communicate article's contents, provided the author's and Journal of Industrial Engineering and Management's names are included. It must not be used for commercial purposes. To see the complete license contents, please visit https://creativecommons.org/licenses/by-nc/4.0/. 